\title{
Crystallization and natural aging of thin films produced by pulsed laser evaporation of rhenium
}

\author{
A.G.Bagmut, I.A.Bagmut, T.K.Murav'ev, D.V.Slabokrug \\ National Technical University "Kharkiv Polytechnical Institute", \\ 21 Frunze Str., 61002 Kharkiv, Ukraine
}

Received October 10, 2012

\begin{abstract}
Rhenium thin-film laser condensates have been obtained by pulsed laser evaporation (PLE) and their structure has been investigated. During annealing and natural aging of films the structural transformations have been examined. As a result of pulsed laser evaporation of Re in vacuum and in the oxygen atmosphere at $\mathrm{P}\left(\mathrm{O}_{2}\right)=10^{-3}$ Torr on $(001)$ $\mathrm{KCl}$ substrates at room temperature, the amorphous films have been formed. Amorphous films become crystalline after annealing. The natural aging in air provides the formation of $\mathrm{ReO}_{3}$ crystals on the film surface. The formation of crystals took place non-uniformly. The $\mathrm{ReO}_{3}$-poor and $\mathrm{ReO}_{3}$-rich crystal zones are formed. The $\mathrm{ReO}_{3}$ crystalline structure is destroyed during annealing in vacuum. The polycrystalline films consisting of $\mathrm{ReO}_{2}$ and $\mathrm{ReO}_{3}$ crystals have been grown as a result of PLE of Re in oxygen atmosphere under $\mathrm{P}\left(\mathrm{O}_{2}\right)$ $=10^{-2}$ Torr on substrates at room temperature.
\end{abstract}

\footnotetext{
Методом импульсного лазерного осаждения (ИЛО) получены тонкопленочные лазерные конденсаты рения и исследована их структура. Изучены структурные изменения, протекающие при отжиге и при естественном старении пленок. При ИЛО Re в вакууме и в атмосфере кислорода при $\mathrm{P}\left(\mathrm{O}_{2}\right)=10^{-3}$ торр на подложках $(001) \mathrm{KCl}$ при комнатной температуре формируются аморфные пленки, которые кристаллизуются при отжиге. Естественное старение на воздухе приводит к формированию на поверхности пленки кристаллов $\mathrm{ReO}_{3}$. Образование кристаллов происходит неоднородно. Формируются зоны как обогащенные, так и обедненные кристаллами $\mathrm{ReO}_{3}$. При отжиге в вакууме кристаллическая структура $\mathrm{ReO}_{3}$ разрушается. В результате ИЛО $\mathrm{Re}$ в атмосфере кислорода при $\mathrm{P}\left(\mathrm{O}_{2}\right)=10^{-2}$ торр на подложках при комнатной температуре формируются поликристаллические пленки, состоящие из кристаллов $\mathrm{ReO}_{2}$ и $\mathrm{ReO}_{3}$.
}

\section{Introduction}

In a solid state, rhenium is a silver-grey metal with hexagonal close-packed crystal lattice. Its melting point is $3180^{\circ} \mathrm{C}$ [1]. Depending on thickness and condensation temperature, either amorphous or crystalline films can be formed in thin-film condition obtained by electron beam evaporation of Re in vacuum [2]. When annealing, the amorphous phase transforms into crystalline one with parameters which are close to those of massive metal. Data on structure of rhenium are provided in the tables of Interna- tional Centre for Diffraction Data JCPDC: $a=0.2760 \mathrm{~nm}, c=0.4458 \mathrm{~nm}$, $a / c=1.6152$ (file 05-0702). According to [3], other modifications observed in Re thin films had impurity character. Perfect epitaxial films of $R e$ were obtained on sapphire substrates $\left(\alpha-\mathrm{Al}_{2} \mathrm{O}_{3}\right)$ by electron beam evaporation in the range of $T_{s}=1000-1200^{\circ} \mathrm{C}$ [4].

At present, there is a lack of data on phase composition and structure of Re films obtained by pulsed laser evaporation (PLE). The aim of the present activity was to obtain rhenium thin-film laser condensates and investigate their structure as well as 


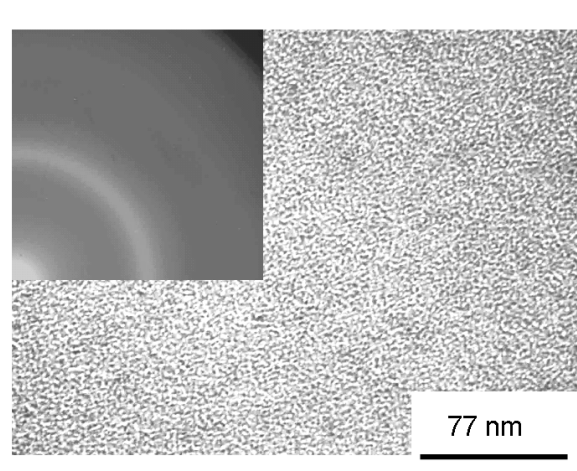

a

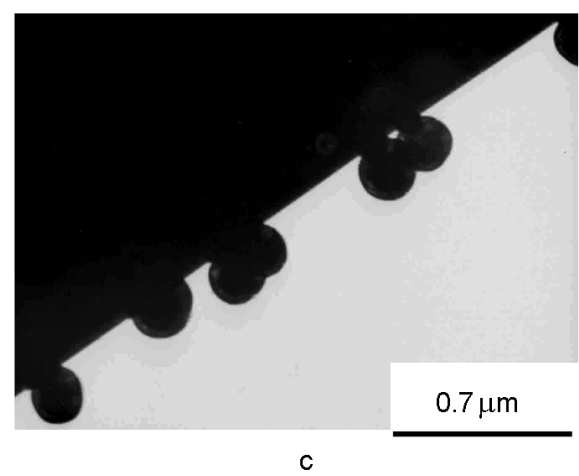

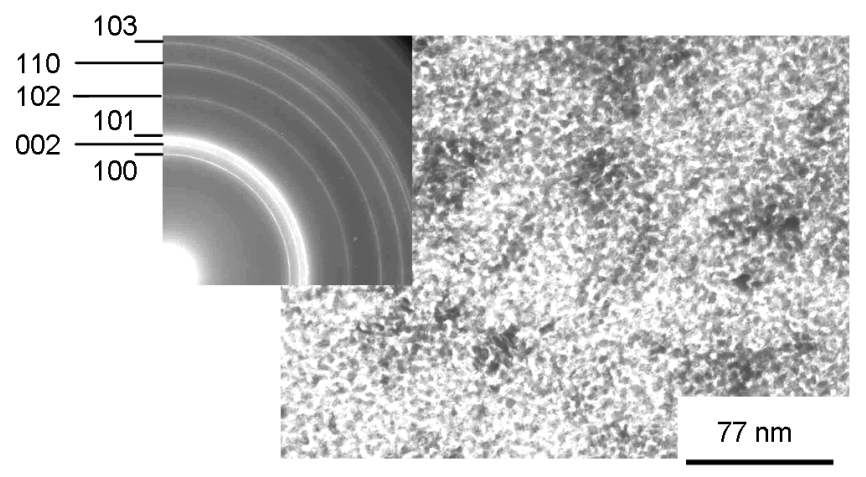

b

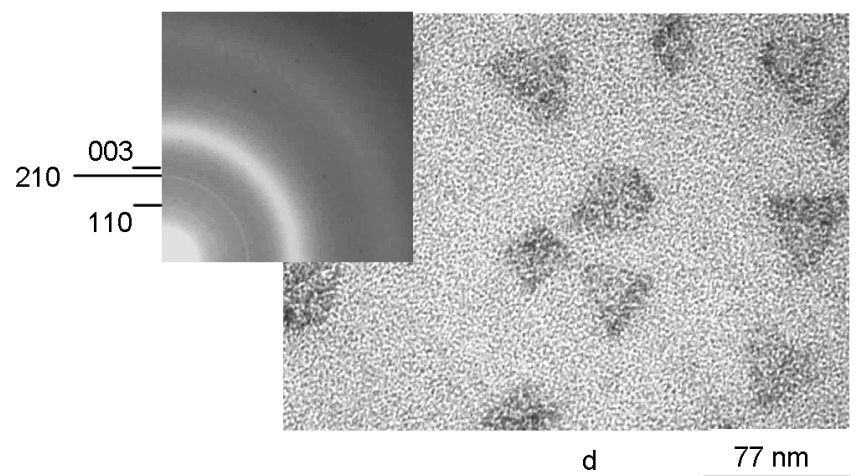

Fig. 1. Electron microscopic images of the films obtained by laser evaporation of Re in vacuum: (a) - an amorphous film after deposition; (b), (c) - crystallization as a result of thermal annealing in a microscope column at $720^{\circ} \mathrm{C}$ and $810^{\circ} \mathrm{C}$, respectively; (d) - formation of $\mathrm{ReO}_{3}$ in amorphous matrix of $\mathrm{Re}$ as a result of natural aging of films in air within 20 days. Electron-diffraction pattern of films are given in the left top corner of micro-images (a), (b) and (d).

structural transformations during annealing and natural aging of such films.

\section{Method and preparation}

Rhenium plate was placed on a rotating table and sputtered by nanosecond laser impulses both in vacuum and in oxygen atmosphere. Laser $\left(\mathrm{Nd}^{3+}\right)$ operated in $q$-modulated mode was irradiated into the chamber through a glass window. Wavelength and pulse frequency was $1.06 \mu \mathrm{m}$ and $25 \mathrm{~Hz}$, respectively. Oxygen was fed into the chamber by means of SNA-2 feeding system at $\mathrm{P}\left(\mathrm{O}_{2}\right)=10^{-3}-10^{-2}$ Torr. Laser erosion plasma was applied onto $(001) \mathrm{KCl}$ substrates at room temperature. The films thicknesses were 20-30 nm. Details of PLE method are given in [5].

To perform investigations, the films were separated from substrates in distilled water and transferred on subject grids. Structural transformations in films have been initiated by their heating directly in a column of electron microscope as well as by their natural aging in air without separation from the substrates. For samples annealing, a specialized adapter have been ap- plied. In this case, the film temperature was determined by heatpower applied to a heater. "In situ" annealing effect in a column of electron microscope and irradiating impact on films have been investigated. The structure of the obtained samples was examined using EM-100L and PEM-100-01 transmission electron microscopes [5].

\section{Results and discussion}

Fig. 1a shows electron-diffraction pattern and electron microscopic image of the film deposited by laser dispersion of rhenium in $10^{-5}$ Torr vacuum on $(001) \mathrm{KCl}$ substrate at room temperature. Diffuse rings and dotted structure on high resolution image indicated the formation of amorphous structure.

Annealing of amorphous films in vacuum with special adapter for heating in a column of electron microscope provided their crystallization. Electron-diffraction pattern and images of the film after annealing at $720^{\circ} \mathrm{C}$ during $1 \mathrm{~min}$ are shown in the Fig. 1b. Interpretation of electron-diffraction pattern is given in Table 1. According to these data, the rhenium polycrystalline film with face- 


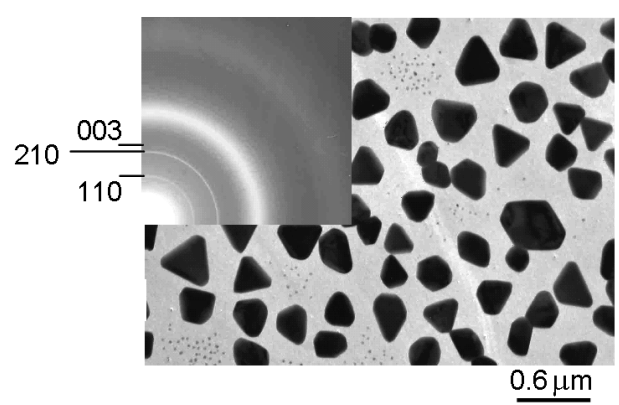

a

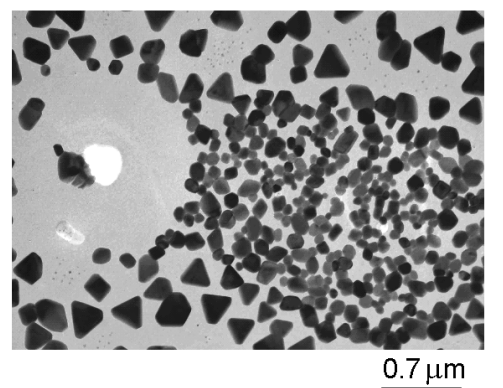

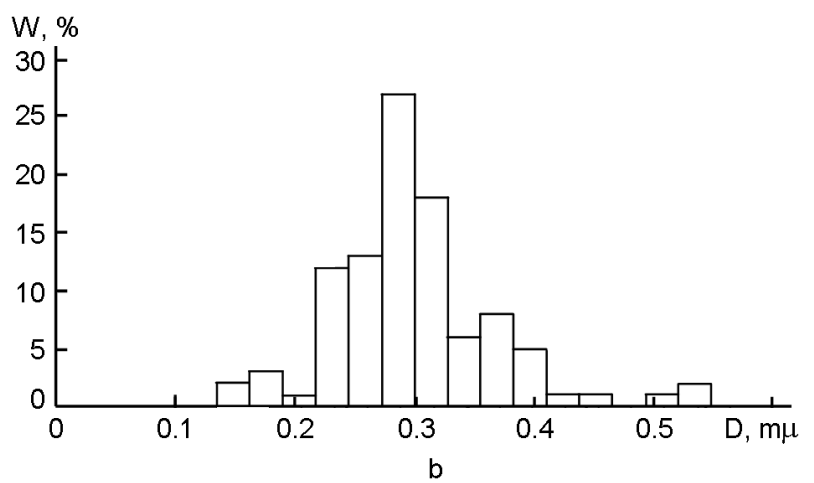

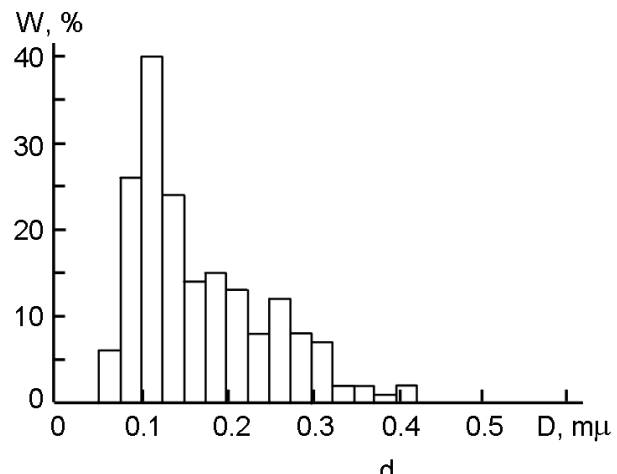

Fig. 2. Structure and distribution of $\mathrm{ReO}_{3}$ crystals on the surfaces of the amorphous film produced by laser evaporation of Re in oxygen atmosphere at $10^{-3}$ Torr after its natural aging in air within 180 days: $(a, b)$ - images and histogram of relative frequencies of grain sizes out of poor and enriched zones; (c, d) - similar for zone enriched with $\mathrm{ReO}_{3}$ crystals.

centered close-packed lattice is formed. The lattice parameters are following: $a=0.2747 \mathrm{~nm}$, $c=0.4459 \mathrm{~nm}, c / a=1.623$. The obtained experimental data are in a good accordance with the data of JCPDC (file 05-0702).

When increasing the annealing temperature to $750^{\circ} \mathrm{C}$, the destructive processes start, which lead to the film discontinuity with the following its subsequent disintegration. As a result, the spherical (more rare faceted) rhenium micro-particles grow as depicted in Fig. 1c. This image shows a so-called film "twisting" that allows interpreting the form of Re micro-particles to be spherical. The growth of Re micro-particles is carried out by diffusive transfer of substance from a film to microspheres. Next, the film becomes thinner and disintegrates. Similar morphological changes were observed earlier when heating fluoroplastic films directly in a column of electron microscope [6].

Natural aging in air of the rhenium amorphous films grown on (001) $\mathrm{KCl}$ substrates provides their oxidation. On the film surface not contacting to a substrate, the $\mathrm{ReO}_{3}$ faceted crystals, grow. Fig. 1d pre- sents the electron-diffraction pattern and electron microscopic image of initial oxidation stage of $\mathrm{Re}$ amorphous film after natural aging during 20 days.

Pulsed laser evaporation of rhenium in oxygen atmosphere at $\mathrm{P}\left(\mathrm{O}_{2}\right)=10^{-3}$ Torr also leads to the formation of amorphous films on substrates at room temperature. Their structure is similar to that shown in Fig. 1a. Trapped during evaporation oxygen intensifies oxidation process under natural aging of the film in air. Fig. 2a presents electron microscopic image of the amorphous film and $\mathrm{ReO}_{3}$ crystals formed as a result of oxidation in air during natural aging within 180 days. Electron-diffraction pattern and its interpretation are presented in the left top corner in Fig. 2a.

It was revealed that formation of $\mathrm{ReO}_{3}$ crystals on the film surface during its natural aging occurs not uniformly. The zones of a roundish form of 1.5-1.6 $\mu \mathrm{m}$ in size are formed. In $\mathrm{ReO}_{3}$-poor zones, we revealed only $1-2$ crystals or they are absolutely absent. In the $\mathrm{ReO}_{3}$-rich zones, the crystals are smaller and their surface density $\rho$ is higher than out of these zones 


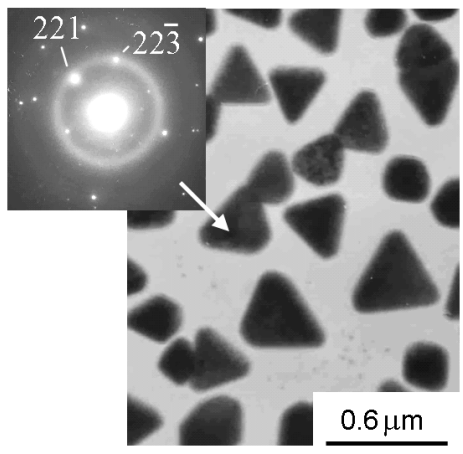

a

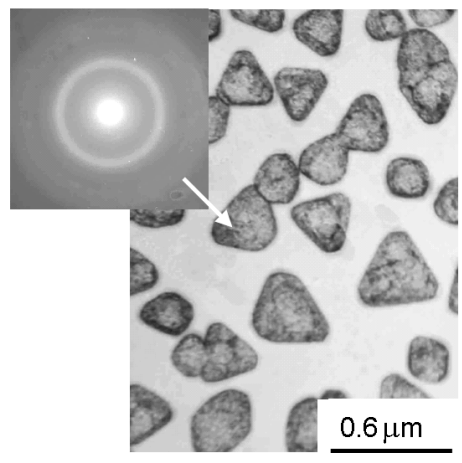

b

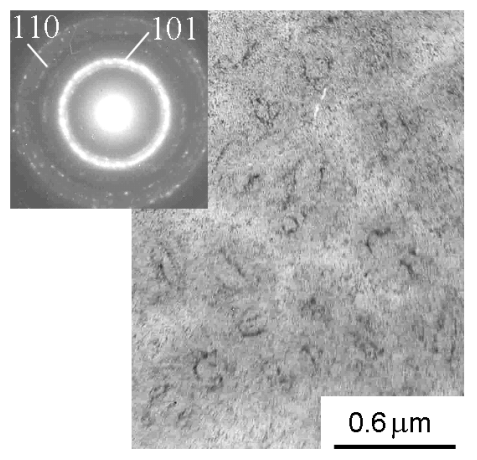

c

Fig. 3. Electronic beam influence on $\mathrm{ReO}_{3}$ crystals: (a) - initial structure; (b) - amorphous state and compound decomposition; (c) - subsequent crystallization with Re segregation. The arrow indicates $\mathrm{ReO}_{3}$ crystal from which the micro-diffraction pattern is taken.

Table 1. Electron-diffraction data from films obtained by PLE in vacuum and in oxygen atmosphere.

\begin{tabular}{|c|c|c|c|c|c|c|c|}
\hline \multirow{2}{*}{$\begin{array}{l}\text { Line } \\
\text { No. }\end{array}$} & \multicolumn{3}{|c|}{ Deposition in vacuum } & \multicolumn{4}{|c|}{ Deposition in oxygen atmosphere at $P\left(\mathrm{O}_{2}\right)=10^{-2}$ Torr } \\
\hline & $d(\AA)$ & $\begin{array}{l}\text { hkl, } \\
\text { phase }\end{array}$ & $\begin{array}{c}d(\mathrm{Re}), \mathrm{nm} \\
(\mathrm{JCPDC} 05-0702)\end{array}$ & $d(\AA)$ & hkl, phase & $\begin{array}{c}\mathrm{d}\left(\mathrm{ReO}_{3}\right), \mathrm{nm} \\
(\mathrm{JCPDC} 40-1155)\end{array}$ & $\begin{array}{c}\mathrm{d}\left(\mathrm{ReO}_{2}\right), \mathrm{nm} \\
(\mathrm{JCPDC} 17-0600)\end{array}$ \\
\hline 1 & 0.2382 & $100-\mathrm{Re}$ & 0.2388 & 0.5294 & $(110)-\mathrm{ReO}_{3}$ & 0.5347 & - \\
\hline 2 & 0.2217 & $002-R e$ & 0.2226 & 0.3452 & $(210)-\mathrm{ReO}_{3}$ & 0.3496 & - \\
\hline 3 & 0.2089 & $101-R e$ & 0.2105 & 0.2830 & $(\mathrm{~T} 02)-\mathrm{ReO}_{2}$ & - & 0.2790 \\
\hline 4 & 0.1622 & $102-\mathrm{Re}$ & 0.1629 & 0.2509 & $(310)-\mathrm{ReO}_{3}$ & 0.2574 & - \\
\hline 5 & 0.1372 & $110-R e$ & 0.1380 & 0.2120 & $(012)-\mathrm{ReO}_{2}$ & - & 0.2140 \\
\hline 6 & 0.1259 & $103-R e$ & 0.1262 & 0.1875 & $\mathrm{ReO}_{2}$ & - & 0.1850 \\
\hline 7 & 0.1190 & $200-R e$ & 0.1195 & & & & \\
\hline 8 & 0.1169 & $112-\mathrm{Re}$ & 0.1173 & & & & \\
\hline 9 & 0.1151 & $201-\mathrm{Re}$ & 0.1154 & & & & \\
\hline
\end{tabular}

Comments: $d$ - interplanar spacing; hkl - Miller indices; JCPDC data from International Centre for Diffraction Data.

(Fig. 2c). The results of processing of statistical data of micro-images having $\mathrm{ReO}_{3}$ crystals are illustrated in Table 2, and also the histograms of relative frequencies are shown in Fig. 2b and 2d. Histograms X-axis indicate the values of microcrystal's diameters $D$, whereas $\mathrm{Y}$-axis shows the values of relative frequencies $W$, defined as follows:

$$
W_{i}=\frac{n_{i}}{n}
$$

where, $n_{i}$ is a number of observations of $D_{i}$ value, and $n$ - amount of sampling. According to the data given in Table 2, an average $\mathrm{ReO}_{3}$ crystals size out of zones are equal to $\sim 0.3 \mu \mathrm{m}$ in the film plane. Their average thickness is $h=0.1 \mu$ (as it was revealed on images having twisted film areas). The crystals arranged with surface density value of $\rho \sim 6 \cdot 10^{8} \mathrm{~cm}^{-2}$.

In the enriched zones the crystals size is $0.17 \mu \mathrm{m}$, and their density turned to be greater: $\rho \sim 5 \cdot 10^{9} \mathrm{~cm}^{-2}$. Comparison of the histograms provided in Fig. $2 \mathrm{~b}$ and $2 \mathrm{~d}$ has shown that the distribution of $\mathrm{ReO}_{3}$ crystal sizes in the enriched zones is more asymmetric in comparison with those out of the zone. According to Table 2 the asymmetry of empirical distribution is as $a_{s}=0.94 \mathrm{in}$ the enriched zones, whereas out of these zones it comprises as $a_{s}=0.88$.

Poor and rich-zones have approximately identical sizes of about 1.5-1.6 $\mu \mathrm{m}$ and are distributed on the sample with surface density of the order $1.5-2.0 \cdot 10^{6} \mathrm{~cm}^{-2}$ (Table 2). This value is almost identical to $\mathrm{KCl}$ crystals dislocation density. Non-uniform distri- 


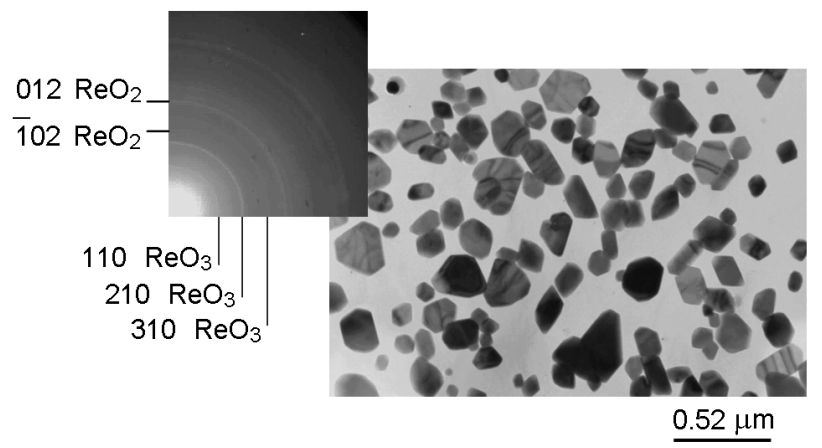

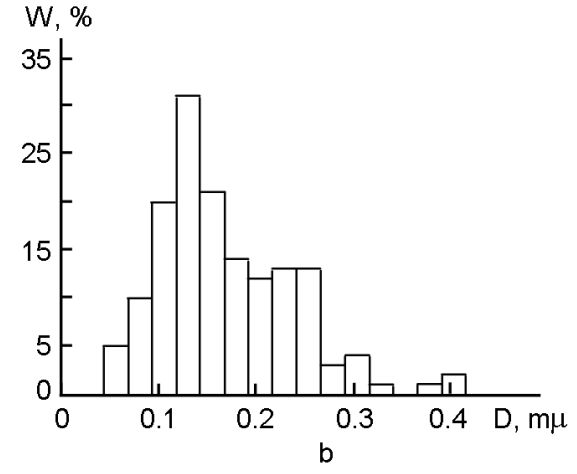

Fig. 4. Laser evaporation of Re in the oxygen atmosphere at $10^{-2}$ Torr: (a) - microstructure image and electron-diffraction pattern taken from the films; (b) - histogram reflecting distribution of sizes of $\mathrm{ReO}_{3}$ micro-crystals.

Table 2. Statistical analysis data of $\mathrm{ReO}_{3}$ crystal sizes and their localization zones in films deposited by laser evaporation of Re in oxygen atmosphere

\begin{tabular}{|c|c|c|c|c|c|}
\hline \multirow{3}{*}{$\begin{array}{l}\text { Characte- } \\
\text { ristics }\end{array}$} & \multicolumn{4}{|c|}{$\begin{array}{c}\text { Evaporation of } \operatorname{Re} \text { at } \mathrm{P}\left(\mathrm{O}_{2}\right)=10^{-3} \text { Torr. } \\
\text { Natural aging during } 180 \text { days }\end{array}$} & \multirow{3}{*}{$\begin{array}{c}\text { Re evaporation at } \\
\mathrm{P}\left(\mathrm{O}_{2}\right)=10^{-2} \\
\text { Torr. } \mathrm{ReO}_{3} \text { and } \\
\mathrm{ReO}_{2} \text { crystals. } \\
\text { After } \\
\text { condensation. }\end{array}$} \\
\hline & \multicolumn{2}{|c|}{$\mathrm{ReO}_{3}$ crystals } & \multicolumn{2}{|c|}{ Zones } & \\
\hline & Out of zones & $\begin{array}{l}\text { In thickening } \\
\text { zones }\end{array}$ & Thickening & De-enrichment & \\
\hline$\rho, \mathrm{cm}^{-2}$ & $5.8 \cdot 10^{8}$ & $4.9 \cdot 10^{9}$ & $1.5 \cdot 106$ & $2.0 \cdot 10^{6}$ & $2.0 \cdot 10^{9}$ \\
\hline$<\mathrm{D}>, \mu \mathrm{m}$ & 0.30 & 0.17 & 1.57 & 1.51 & 0.17 \\
\hline$\sigma_{v}, \mu \mathrm{m}$ & 0.07 & 0.08 & - & - & 0.07 \\
\hline $\mathrm{V}, \%$ & 23.6 & 45.6 & - & - & 41.3 \\
\hline$a_{s}$ & 0.88 & 0.94 & - & - & 0.87 \\
\hline
\end{tabular}

Comments: $\rho$ - surface density; $<\mathrm{D}>-$ average size; $\sigma_{v}$ - sample standard deviation; $\mathrm{V}-$ coefficient of variation as $\frac{\sigma_{v}}{\langle D\rangle} \cdot 100 \% ; a_{s}-$ asymmetry of empirical distribution

bution of $\mathrm{ReO}_{3}$ particles on a surface of amorphous film can be interpreted as decorating effect of $(001) \mathrm{KCl}$ defect surface. The crystal lattice deforms in areas in which the dislocations normal to the film surface are intercross $\mathrm{KCl}$ free surface.

In these areas oxygen capture efficiency by the growing rhenium film differs from those surface crystal-substrate areas where dislocations outlets are absent. During aging, $\mathrm{ReO}_{3}$ crystals are not practically formed in the areas in which oxygen concentration is reduced in comparison with its average value in the film. Segregation of $\mathrm{ReO}_{3}$ crystals is intensified in the oxygen enriched areas. Similar areas were revealed earlier when decorating the surface of alkali-halide crystals by gold [7].

It was found that the influence of an electronic beam in a microscope column on an amorphous film with crystals proceeds in two stages. At the first stage, destruction of $\mathrm{ReO}_{3}$ crystal lattice took place (Fig. 3a and $3 \mathrm{~b})$. The second stage provides the crystallization of the amorphous film with $\mathrm{Re}$ segregation due to electronic beam intensification (Fig. 3c).

During evaporation of $\mathrm{Re}$ in oxygen atmosphere at $\mathrm{P}\left(\mathrm{O}_{2}\right)=10^{-2}$ Torr on $(001) \mathrm{KCl}$ substrates at room temperature the faceted crystals have been formed (Fig. 4), for which $\quad<D>=0.17 \mu \mathrm{m}, \quad \rho=2 \cdot 10^{9} \mathrm{~cm}^{-2}$ (Table 2). Electron-diffraction data, given in the left top corner in Fig. 2a, showed that $\mathrm{ReO}_{3}$ crystals with hexagonal lattice as well as $\mathrm{ReO}_{2}$ monoclinic crystals were grown (Table 1).

\section{Conclusions}

Amorphous films have been formed on (001) $\mathrm{KCl}$ substrates as a result of pulsed laser evaporation of $R e$ in vacuum and in 
oxygen atmosphere at $\mathrm{P}\left(\mathrm{O}_{2}\right)=10^{-3}$ Torr at room temperature.

The first order phase transition to the crystalline state took place at annealing of amorphous thin-film laser condensates of $\mathrm{Re}$ in vacuum. The crystals of $\mathrm{ReO}_{3}$ are formed on Re thin film surface not contacting with the substrate as a result of natural aging of the amorphous laser condensates. Process of natural aging of the films obtained by laser evaporation of $R e$ in oxygen atmosphere at $\mathrm{P}\left(\mathrm{O}_{2}\right)=10^{-3}$ Torr proceeds more intensively in comparison with aging of the films produced in vacuum. In 180 days the thickness of $\mathrm{ReO}_{3}$ crystals reaches $0.14 \mu \mathrm{m}$, whereas the average grain size in the film plane reaches $0.3 \mu \mathrm{m}$. The decoration effect of the substrate by $\mathrm{ReO}_{3}$ crystals was revealed. The formation of $\mathrm{ReO}_{3}$ crystals on the amorphous film surface has non-uniform character. The zones of 1.5-1.6 $\mu \mathrm{m}$ size enriched with $\mathrm{ReO}_{3}$ crystals, and also zones where these crystals are practically absent have been formed. The total density of such zones on the film surface comprised $\sim 3.5 \cdot 10^{6} \mathrm{~cm}^{-2}$, and this correlates well with dislocations density in $\mathrm{KCl}$ substrate. During pulsed laser evaporation of Re in oxygen atmosphere at $\mathrm{R}\left(\mathrm{O}_{2}\right)=10^{-2}$ Torr on the substrates at room temperature the polycrystalline films consisting of $\mathrm{ReO}_{2}$ and $\mathrm{ReO}_{3}$ crystals have been formed. The structure of $\mathrm{ReO}_{3}$ crystal is destroyed during annealing in vacuum. The formed non-crystalline solid state is metastable, and the additional subsequent annealing initiates its crystallization with formation of polycrystalline Re.

\section{References}

1. E.G.Rakov, I.D.Troshkina, Rhenium, Chemical Encyclopaedia, Scientific Publisher "Big Russian Encyclopaedia", Moscow (1995), v.4, p.464 [in Russian].

2. I.Yu.Protsenko, V.M.Severin, A.F.Skorobagat'ko, Kristall und Tecnik., 11, 941 (1976).

3. I.P.Burik, L.V.Odnodvorets, J. Nano- and Electron. Phys., 1, 24 (2009)

4. V.A.Komashko., Yu.V.Titenko, I.V.Belousov, I.D.Voitovich, Ukr. Phys. J., 23, 155 (1978).

5. A.G.Bagmut, S.N.Grigorov, V.A.Zhuchkov et al., Functional Materials, 13, 507 (2006).

6. A.G.Bagmut, V.P.Nikitskiy, V.F.Pusan et al., High-molecular comp., (A) 24, 773 (1982).

7. G.I.Distler, V.P.Vlasov, Yu.M.Gerasimov, Dekoration of Solid Surfaces, Science,Moscow (1976) [in Russian].

\title{
Кристалізація та природне старіння плівок, осаджених лазерним випаровуванням Re
}

\author{
О.Г.Багмут, І.О.Багмут, Т.К.Мурав’йов, Д.В.Слабокруг
}

\begin{abstract}
За допомогою методу імпульсного лазерного осадження (ІЛО) одержано тонко плівкові лазерні конденсати ренію та вивчено їх структуру. Досліджено структурні зміни, які мають місце під час відпалювання та під час природного старіння плівок. При IJO Re у вакуумі і в атмосфері кисню при $\mathrm{P}\left(\mathrm{O}_{2}\right)=10^{-3}$ торр на підкладках $(001)$ $\mathrm{KCl}$ при кімнатній температурі формуються аморфні плівки, які кристалізуються під час відпалу. Природне старіння на повітрі приводить до формування на поверхні плівки кристалів $\mathrm{ReO}_{3}$. Maє місце неоднорідний розподіл кристалів. Формуються зони, які збагачені, так i зони, які збіднені кристалами $\mathrm{ReO}_{3}$. Під час відпалу у вакуумі кристалічна структура $\mathrm{ReO}_{3}$ руйнується. В результаті IЛO $\mathrm{Re}$ в атмосфері кисню при $\mathrm{P}\left(\mathrm{O}_{2}\right)=10^{-2}$ торр на підкладках при кімнатній температурі формуються полікристалічні плівки з кристалів $\mathrm{ReO}_{2}$ i $\mathrm{ReO}_{3}$.
\end{abstract}

